\title{
Plant community diversity in the Chobe Enclave, Botswana: Insights for functional habitat heterogeneity for herbivores
}

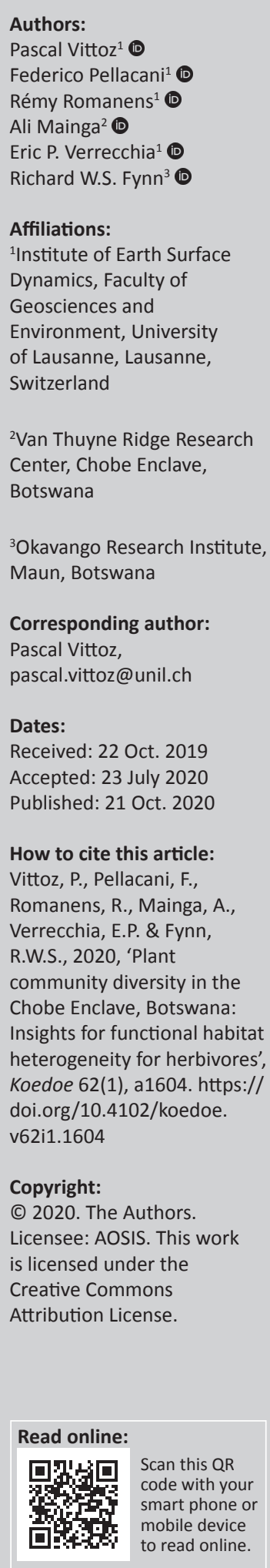

Precise vegetation descriptions and maps are essential tools for the management of natural areas, as well as for understanding animal habitat use. The Chobe Enclave (CE), adjacent to the Chobe National Park and the Chobe Forest Reserve, forms a critical dry season range for many large herbivores. As a tool for future management and studies about wildlife habitat use and migration, this study proposed to describe the plant communities in the CE and to study their relationships with microtopography and soils. Plant species were inventoried in 82 sampling plots $(40 \times 20 \mathrm{~m})$, covering the vegetation diversity recognised by an unsupervised classification (Landsat images, 30-m resolution). A hierarchical clustering classified the inventories in eight plant communities, mapped with a supervised classification. This study was conducted in parallel with a soil study. Soil variations and degree of flooding largely determine community composition. Floodplains along the Linyanti River and dambos (concentrating local run off from rainfall) provide reliable green forage for wildlife during the dry season. Adjacent to floodplains, riverine forests also maintain green browse and grazing well into the dry season. In drylands, vegetation is largely determined by soil texture. Forests dominated by Baikiaea plurijuga occupy the acidic, red sands in the east, while sandveld vegetation grows on deep sands in paleo-river channels. These habitats support dominant grasses, which provide important forage for grazers during the wet season. Finally, woodlands dominated by Colophospermum mopane, characterised by sodium-rich and alkaline soils, enable herbivores to meet their mineral requirements during reproduction.

Conservation implications: Our soil and vegetation studies provide important insights into factors determining plant communities. Their diversity and close vicinity play a critical role in enabling herbivores to adapt to seasonal variations in forage quantity and quality. Results will enable researchers to gain insights into animal habitat seasonal use in the Chobe Enclave.

Keywords: plant community ecology; vegetation map; soil; water availability; microtopography.

\section{Introduction}

Biodiversity is threatened worldwide by human activities, directly by its land-use change and introduced species, as well as indirectly by pollution and climate change (Sala et al. 2000). Although many studies attempted to predict potential future changes (McClean et al. 2006), only precise and georeferenced data (e.g. species lists) will be able to monitor global change impacts in the future. In plant sciences, exhaustive species inventories are directly beneficial to study their distribution in the landscape and to understand how biodiversity is related to environmental factors. Moreover, such exhaustive plant surveys provide information on the dominant species, their co-occurrence with other species and are the basis for the classification of plant communities (Ewald 2003). In relation to respective biotic and abiotic factors, they also help to obtain a better knowledge of species autoecology (e.g. Ischer et al. 2014). At a landscape scale, the classification of plant communities remains an important tool for improved management and conservation of species and ecosystems and provides the basis for vegetation maps (De Cáceres et al. 2015).

Vegetation maps and descriptions offer an overview of the distribution of ecosystems and associated environmental conditions. They assist in understanding and studying wildlife distribution and migration and improving the management of protected areas (Bennitt, Bonyongo \& Harris 2014; Fynn et al. 2014; Sianga \& Fynn, 2017). In the process of vegetation map development, field data are still an essential step to get a high-quality classification. In addition, 
remote sensing data are a powerful aid to prepare field work and to delineate plant communities for large areas (Walker et al. 2016).

The Chobe Enclave (CE) is located between two conservation areas in northern Botswana (Jones 2002), as well as conservancies directly across the border in Namibia. Situated along the Linyanti River, it provides suitable habitat for large populations of mega herbivores all around the year, especially coming from surrounding conservation areas during the dry season. Apart from wild herbivores, it is grazed by cattle of a small number of villages (Chase 2013). This situation can lead to conflicts between pastoralists and wild fauna. It is therefore important that the seasonal and daily use of the territory by fauna is investigated to ensure optimal management to the benefit of both pastoralists and wildlife. A typology and vegetation map of the region can provide useful information in this context. Detailed data about the vegetation of the CE are scarce. A vegetation map covering the much larger region of the Savuti-Mababe-Linyanti ecosystem exists, but it has an insufficient spatial resolution for efficient management at the local scale. Our study is novel in the sense that it was accompanied by a detailed soil study (Romanens et al. 2019), which provides key insights into mechanisms underlying plant community composition, as well as for understanding herbivore habitat selection. Hence, our study provides the first detailed soil-vegetation classification and map. This simultaneous soil study showed an unexpected soil diversity in a relatively flat region on homogeneous sand-dominated bedrock (Romanens et al. 2019). This diversity is representative for soil conditions in and around the CE. We can expect that plant communities have a corresponding diversity.

Therefore, the aims of this study in the CE are (1) to describe the plant communities, (2) to understand their distribution in the landscape in relation to topography, substrate and hydrology and (3) to develop a vegetation map that can be used for animal habitat use studies and conservation planning.

\section{Study area}

The CE (17.94 ${ }^{\circ} 18.36^{\circ} \mathrm{S}, 23.93^{\circ} 24.59^{\circ} \mathrm{E}$; $930 \mathrm{~m}$ above sea level), with an area of $1690 \mathrm{~km}^{2}$, is separated from Namibia by the Linyanti River (Figure 1). It is part of the $440000 \mathrm{~km}^{2}$ KavangoZambezi Trans-Frontier Conservation Area (KAZA-TFCA; Pricope et al. 2015). The CE is managed by the CE Community Trust (CECT; Pricope et al. 2015), but it has a lower protection status than the adjacent Chobe National Park.

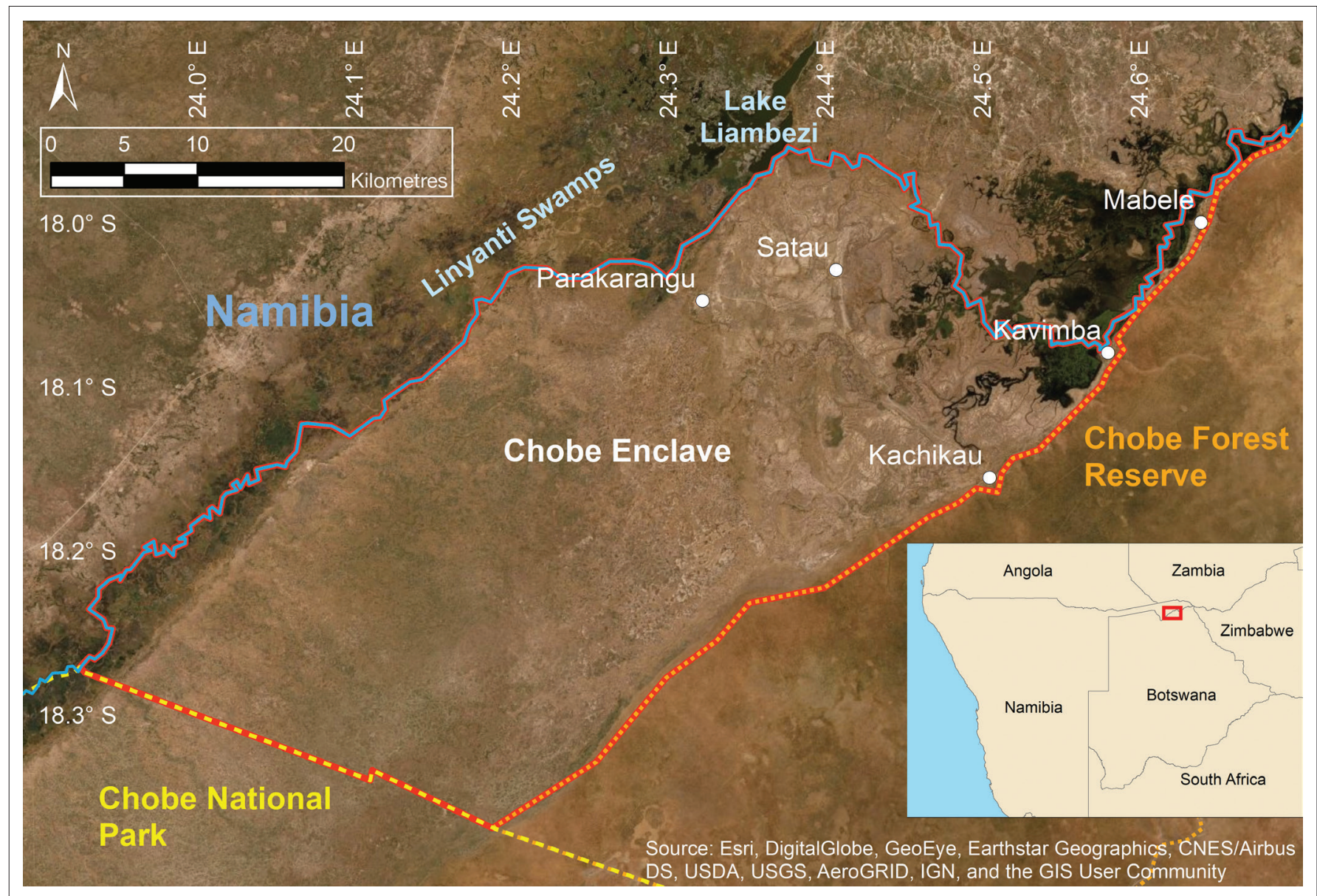

Source: Adapted from Google Earth; ESRI, 2019, World imagery and national geographic base maps, ESRI, DigitalGlobe, GeoEye, Earthstar Geographics, CNES/Airbus DS, USDA, USGS, AeroGRID, IGN, and the GIS User Community; coordinates in decimal degrees.

FIGURE 1: Location of the Chobe Enclave in Botswana (delimited by the red rectangle in inset), between Namibia in the north and west, Chobe National Park in the south and Chobe Forest Reserve in the east. The limits of the Chobe Enclave are delineated by the red line, including the border with Namibia, which follows the Linyanti River (in blue). 
The CE is characterised by a wet season between November and March with a mean annual rainfall of $650 \mathrm{~mm}$ (maximum daily temperatures $30^{\circ} \mathrm{C}-40^{\circ} \mathrm{C}$ ) and a dry season between April and October (Jones 2002). Evapotranspiration is higher than rainfall for all months of the year.

The CE is part of the Kalahari Basin dominated by sandy soils. The CE is separated from Namibia by the Linyanti geological fault (along which the Linyanti River is forming swamps), and from the Chobe Forest Reserve by the Chobe geological fault with $35 \mathrm{~m}-40 \mathrm{~m}$ difference in elevation (Kinabo et al. 2008; McCarthy 2013). During the Late Pleistocene and Early Holocene, the CE was a large delta (Burrough \& Thomas 2008). These conditions locally induced the deposition of lacustrine carbonate and diatomite layers on top of the original sand layers (Diaz et al. 2019), and sand dunes were stabilised on the shores of palaeolakes (Burrough \& Thomas 2008). Islands probably emerged by accumulation of salts because of plant evapotranspiration - a process comparable to the present-day Okavango Delta system (McCarthy et al. 2012). The southwestern part of the system became disconnected from the Linyanti River and subsequently dried up following the uplift of the Linyanti geological fault. Then erosion removed the sand around the carbonate layers. These layers are nowadays visible as platforms at about $2 \mathrm{~m}$ above the sand plains (Diaz et al. 2019). Channels became filled with sand. Fossil islands and channels, carbonate platforms and sand dunes shape the present-day complex microtopography. Apart from this microtopography and faults, the CE is almost completely flat with a mean slope of $0.4 \%$ from southwest to northeast and a mean slope of $0.55 \%$ from northwest to southeast. A more complete description of the geology and geomorphology is given in the parallel study conducted on soils (Romanens et al. 2019).

The local human population is limited to five villages distributed in the northeast of the CE, mostly close to the boundary with a total of approximately 3400 inhabitants (Figure 1; Chase 2013). Agriculture mostly consists of extensive cattle breeding, whilst small crop fields are located close to and around the village areas. An estimated 4800 cattle are kept within a $10-\mathrm{km}$ radius around the villages, although only a minority (600-700) would be grazing in the CE (Chase 2013).

Surrounded by species-rich protected areas (Chobe National Park and Chobe Forest Reserve), the CE shelters many large herbivores as well. Chase (2013) estimated the following wildlife populations in the CE during the dry season of 2011: 9003 elephants, 2443 buffaloes, 94 giraffes, 58 hippopotami and 1492 zebras. Important populations of roan and sable antelopes, eland, impala and kudu are also living in the area.

\section{Materials and methods \\ Unsupervised classification and vegetation sampling}

Three Landsat 8 images of the CE were selected representing different seasons in 2015 (Appendix 1): February (wet season),
May (beginning of dry season) and September (middle to end of dry season). Bands 2-7 were retained for vegetation mapping: blue, green, red, near infrared and two bands of short-wave infrared. The three scenes were stacked into a single raster $(30 \times 30 \mathrm{~m}$ ground resolution), which contained the selected six bands for the three periods.

Unsupervised classification was run on this raster with the K-means non-hierarchical clustering algorithm (Hartigan 1975), according to pixel spectral signature. On the basis of patterns visually identifiable on Landsat images and Google Earth exploration and from previous authors' observations in the region, 10 classes were retained as a first division in plant communities.

Roads and tracks were added from Google Earth images and authors' experience of the region to select accessible sites. A 250-m buffer around tracks was applied to restrict the time necessary to reach the sampling plots on foot. Within this buffer, 10 sampling plots were randomly selected for each class.

As a result of weather-related logistic constraints, we had to modify the original sampling strategy. Ultimately, most sampling plots were selected directly in the field, in an area closer to base camp (Van Thuyne Ridge Research Center). In spite of this, the unsupervised classification was used to ensure a balanced sampling between initial classes. Only homogeneous areas chosen according to the unsupervised classification were retained for plant surveys (see Appendices 2 and 3 for the final distribution of the sampling plots).

\section{Field descriptions and vegetation classification}

For each plot, $40 \times 20 \mathrm{~m}$ of homogeneous vegetation was surveyed between mid-January and mid-March 2017. This area was large enough to contain almost the complete diversity of plant species representative of the plant community, even for tree species with low cover (woodlands), and was similar to former surveys in the same region (Sianga \& Fynn 2017). Plot coordinates were recorded by using a global positioning system (GPS) device. Mean tree height, total tree cover, shrub cover and herb cover were estimated visually in percentage for each plot. All woody, grass and forb species were identified and their respective cover visually estimated in percentage. Nomenclature followed The Plant List (http:/ / www.theplantlist.org, version 1.1) and Kyalangalilwa et al. (2013) for the former Acacia. For woody species, specimens exceeding $2 \mathrm{~m}$ in height were considered as trees, whereas smaller specimens were considered as shrubs. This separation gave a precise description of the vertical structure, although only the highest of both values (tree or shrub cover) was retained for subsequent analyses. As a result of time constrains, soil profiles were dug and described for the first 36 of 82 plots only. For 16 soil profiles, representing the whole range of observed variations (microtopography, plant communities), laboratory analyses completed the description $\left(\mathrm{pH}_{\text {Water }}\right.$, cation exchange capacity [CEC], total organic carbon, soil texture). To ensure that 
these profiles included all soil variations, a total of 27 supplementary soil profiles were described in the field from cores extracted with a soil auger. The most important physicochemical parameters for plant growth are grouped per plant community and reported in the 'Results' section.

Statistical analyses were conducted by using $R$ software ( $R$ Development Core Team; www.R-project.org). To reduce the weight of dominant species, cover values were squareroot transformed (Wildi 2010). A similarity matrix was calculated (Bray-Curtis distance) to build a dendrogram with Ward's minimum variance method. The number of groups was defined by an approach based on the IndVal method (Dufrêne \& Legendre 1997). This method calculates indicator values for each species based on its fidelity and its relative abundance in a predefined number of groups. A randomisation procedure evaluates the significance of the species indicator values. This was applied iteratively to different numbers of groups, considering that the most meaningful group number corresponds to the highest number of significant indicator species $(p<0.05)$ and the lower overall mean $p$-value. Eight groups were considered as the most relevant division, coherent with field observations.

Diagnostic species of each group were extracted by calculating the indicator value based on species presence only (Dufrêne \& Legendre 1997) and evaluated by using a randomisation test. Diagnostic species occurring in $<40 \%$ of plots were not retained because they are of little help in recognising the plant community in the field (except those with a mean cover $>2 \%$ ). Finally, for each plot, species richness, Simpson diversity and evenness were calculated.

\section{Vegetation mapping}

Once the eight plant communities were defined, vegetation was mapped with a supervised classification (or semiautomatic classification) based on the previously used 18 bands. To provide examples of the variety of spectral signatures that are associated with each plant community, training polygons were manually selected for homogenous areas around each plot (Schmidt 2017), based on field knowledge and Google Earth.

The range of spectral values occupied by the respective training sites was used to define a multidimensional parallelepiped (with as many dimensions as bands used) for each plant community, according to the Land Cover Signature Classification (Perumal \& Bhaskaran 2010) provided by the Semi-automatic Classification Plugin (Gongedo 2017). Each pixel was classified depending on the parallelepiped in which it was included. Pixels whose signature overlapped two or more parallelepipeds were classified by using the minimum distance algorithm. This algorithm calculates the Euclidean distance between the spectral signatures of the pixel and training sites and assigns pixels to the nearest plant community.

\section{Results}

A total of 383 species were encountered in the 82 sample plots. The eight plant communities comprise three grassland, three woodland and two forest communities (Table 1; Figure 2; Appendix 4). Site 33, originally classified in the wet floodplains (see definition in section Wet floodplain), was excluded from subsequent analyses because of its unique composition and structure: a termite mound in a floodplain, but with a heterogeneous composition.

\section{Aristida junciformis - Aristida meridionalis grassland}

This unit comprises low cover grasslands (mean cover $42.2 \% \pm 15.6 \%$; Table 1) established on sandy and thick alluvial deposits. These grasslands are flooded at a low frequency (possibly not each year). However, the observed water whilst digging soil pits and the general absence of trees suggest that they are still under the seasonal influence of a high water table. The very high sand proportion ( $98 \%)$ of the substrate is related to the lowest content of organic matter $(<0.1 \%)$, both explaining the low cation exchange capacity (CEC; $<0.4 \mathrm{cmol}^{+} \mathrm{kg}^{-1}$; Table 2$)$. The soils were classified as Arenosols by Romanens et al. (2019). Amongst the diagnostic species, the dominant Aristida meridionalis and A. junciformis, Schizachyrium jeffreysii and Hyperthelia dissoluta are all Poaceae with low palatability and nutritional value (Roodt 2015). Other diagnostic species are Hermannia eenii, Bulbostylis hispidula, Dicerocaryum eriocarpum and Pycreus pelophilus (Online Appendix 2). With a mean of $21.9 \pm 4.8$ species, plots belonging to this unit were amongst the species poorest (Figure 3). This is probably related to three stressing factors: a seasonally high water table, alternating with dry conditions, and very low nutrient availability because of the low CEC.

TABLE 1: Mean tree cover, tree height, shrub cover and herb cover for the eight plant communities.

\begin{tabular}{|c|c|c|c|c|c|}
\hline Plant community & Number of plots & Tree cover (\%) & Tree height (m) & Shrub cover $(\%)$ & Herb cover $(\%)$ \\
\hline A. Aristida junciformis - Aristida meridionalis grassland & 9 & 0.3 & - & 0.6 & 42.2 \\
\hline B. Ipomoea chloroneura - Oxygonum alatum woodland & 20 & 15.8 & 3.7 & 10.6 & 82.4 \\
\hline C. Baikiaea plurijuga - Baphia massaiensis forest & 5 & 34.6 & 6.6 & 11.4 & 87.0 \\
\hline D. Colophospermum mopane - Jasminum stenolobum woodland & 9 & 17.3 & 3.9 & 12.7 & 56.2 \\
\hline E. Eragrostis superba-Combretum hereroense woodland & 13 & 16.9 & 4.7 & 10.1 & 89.7 \\
\hline F. Croton megalobotrys - Setaria verticillata forest & 9 & 51.4 & 8.4 & 8.0 & 99.8 \\
\hline G. Geigeria schinzii - Setaria sphacelata grassland & 10 & 0.1 & - & 0.7 & 99.8 \\
\hline H. Wet floodplain & 6 & 0.7 & - & 0.7 & 89.3 \\
\hline
\end{tabular}



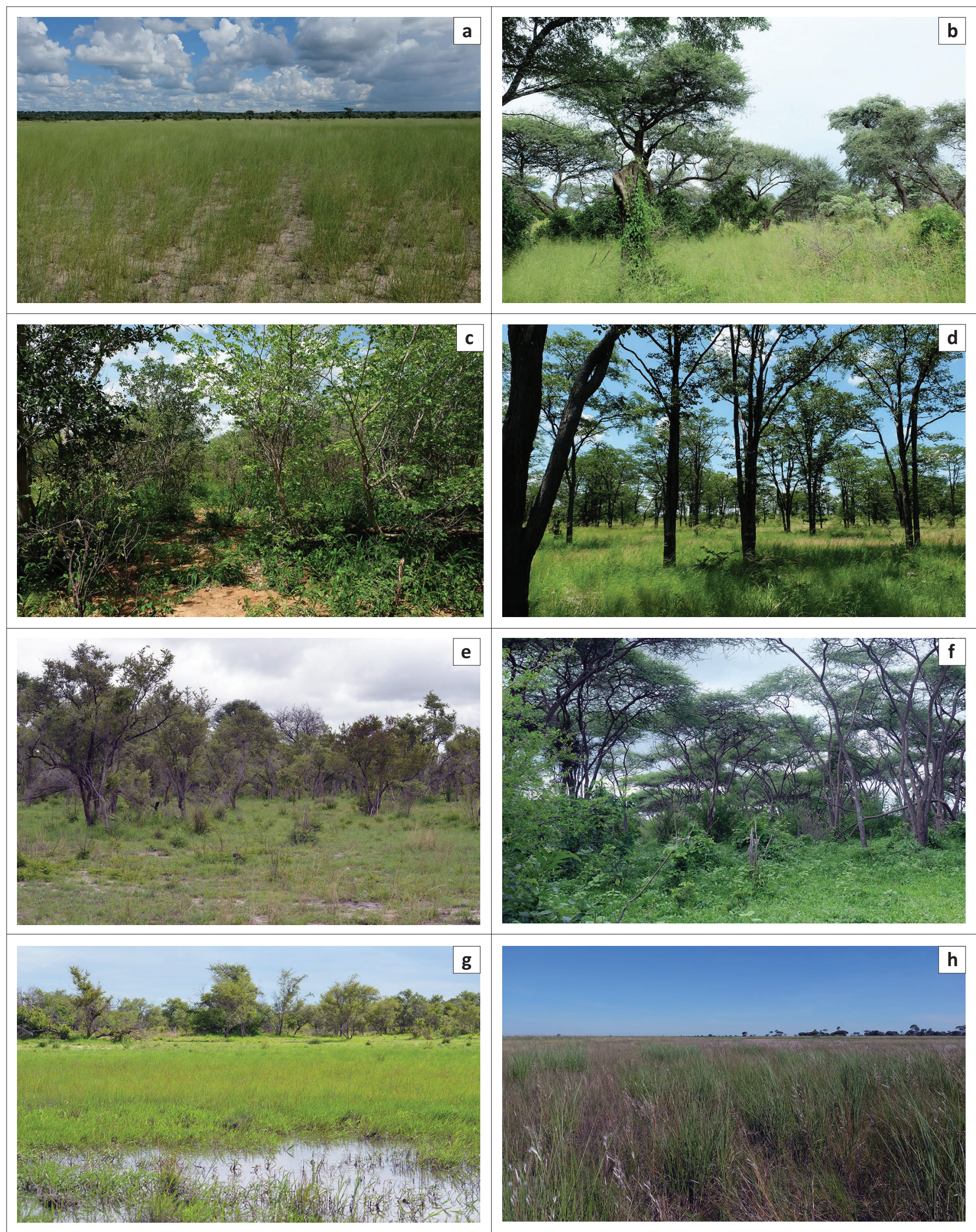

Source: Photos provided (a, b, c, d, f, h) by F. Pellacani; (e, g) P. Vittoz

FIGURE 2: Overview of plant communities in the Chobe Enclave. (a) Aristida junciformis - Aristida meridionalis grassland, dominated by A. junciformis and A. meridionalis (plot 71); (b) Ipomoea chloroneura - Oxygonum alatum woodland, with Terminalia sericea, Vachellia erioloba and Panicum maximum (plot 48); (c) Baikiaea plurijuga - Baphia massaiensis forest (plot 8); (d) Colophospermum mopane - Jasminum stenolobum woodland, dominated by C. mopane and Aristida adscensionis (plot 36); (e) Eragrostis superba - Combretum hereroense woodland, dominated by C. hereroense and Digitaria eriantha (plot 3); (f) Croton megalobotrys - Setaria verticillata forest, dominated by Vachellia tortilis (plot 16); (g) Geigeria schinzii - Setaria sphacelata grassland, after a heavy rain; (h) Wet floodplain, dominated by Andropogon eucomus (plot 81). 
TABLE 2: Ranges of selected physicochemical parameters measured in soil samples between 0-15 cm and 15-30 cm of profiles described by Romanens et al. (2019), and grouped by plant communities.

\begin{tabular}{|c|c|c|c|c|c|c|c|c|}
\hline Plant community & Profile number & Soil group & $\mathrm{pH}$ & $\operatorname{CEC}\left(\mathrm{cmol}^{+} \mathrm{kg}^{-1}\right)$ & TOC (\%) & Clay (\%) & Silt (\%) & Sand $(\%)$ \\
\hline A. Aristida junciformis - Aristida meridionalis G. & 34 & Arenosol & $5.7-6.6$ & $<0.4 \dagger$ & $<0.1 \dagger$ & $0.5-0.6 \dagger$ & $0.6 \dagger$ & $98.8-98.9 \%$ \\
\hline B. Ipomoea chloroneura - Oxygonum alatum W. & $12,18,29$ & Arenosol & $6.1-7.1$ & $0.6-2.1$ & $0.1-0.5$ & $0.7-1.1$ & $2.5-7.2$ & $91.7-96.8$ \\
\hline C. Baikiaea plurijuga - Baphia massaiensis $\mathrm{F}$. & 8 & Arenosol & $5.7-6.0 \dagger$ & $0.7-1.1$ & $0.2-0.3$ & $0.8-1.3$ & $3.2-3.4$ & $95.3-96.0$ \\
\hline \multicolumn{9}{|l|}{ D. Colophospermum mopane - Jasminum stenolobum W. } \\
\hline $\mathrm{T}$ & 36 & Solonetz & $7.0-8.2$ & $1.9-2.8$ & $0.1-0.4$ & $2.6-3.6$ & $14.0-16.5$ & $79.9-83.5$ \\
\hline $\mathrm{S}$ & 35 & Solonchak & $9.4-10.2 \ddagger$ & $11.6-15.6$ & $0.5-0.6$ & $12.3-13.9$ & $57.7-58.2$ & $27.9-30.0$ \\
\hline E. Eragrostis superba-Combretum hereroense W. & $1,13,30$ & Kastanozem & $7.8-8.8$ & $7.3-22.7$ & $0.3-1.6$ & $14.2-20.3 \div$ & $42.8-61.4$ & $20.5-34.2$ \\
\hline F. Croton megalobotrys - Setaria verticillata F. & $14,21,27$ & Kastanozem & $7.6-8.9$ & $5.2-8.2$ & $0.4-1.0$ & $4.3-8.3$ & $14.9-33.2$ & $60.2-80.8$ \\
\hline G. Geigeria schinzii - Setaria sphacelata G. & 19,23 & Chernozem, Phaeozem & $6.5-8.8$ & $21.4-35.9 \%$ & $3.1-5.1 \div$ & $11.4-14.8$ & $58.8-68.2 \ddagger$ & $19.1-28.7 \dagger$ \\
\hline
\end{tabular}

Source: Romanens, R., Pellacani, F., Mahinga, A., Fynn, R., Vittoz, P. \& Verrecchia, E.P., 2019, 'Soil diversity and major soil processes in the Kalahari basin, Botswana', Geoderma Regional 19(1), e00236. https://doi.org/10.1016/j.geodrs.2019.e00236; IUSS Working Group WRB, 2014, World reference base for soil resources 2014: International soil classification system for naming soils and creating legends for soil maps, FAO, Rome

Note: Soils are classified according to IUSS Working Group WRB (2014)

Colophospermum mopane - Jasminum stonolobum woodlands are divided into a tall community $(\mathrm{T})$ and a low, shrubby community (S).

CEC, cation exchange capacity; $\mathrm{F}$, forest; $\mathrm{G}$, grassland; $\mathrm{pH}, \mathrm{pH}_{\text {water }}$; TOC, total organic carbon; $\mathrm{W}$, woodland.

$\dagger$, Lowest value of the column.

$\$$, Highest value of the column.

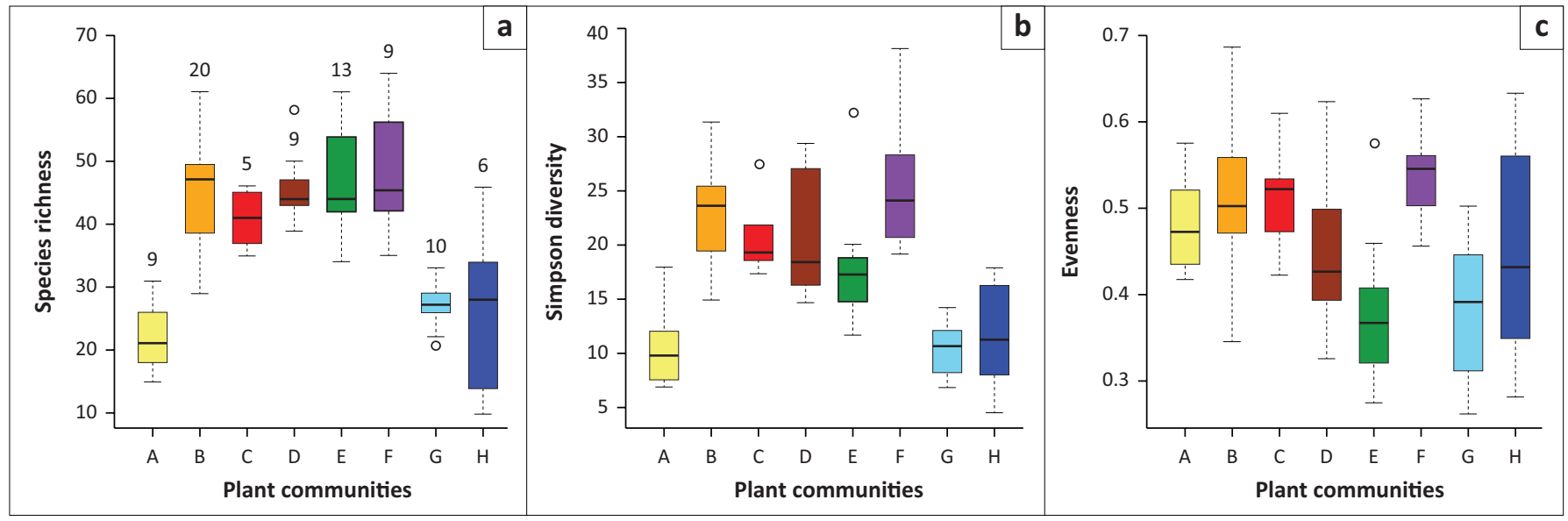

A. Aristida junciformis - Aristida meridionalis grassland; B. Ipomoea chloroneura - Oxygonum alatum woodland; C. Baikiaea plurijuga - Baphia massaiensis forest; D. Colophospermum mopane Jasminum stenolobum Woodland; E. Eragrostis superba - Combretum hereroense woodland; F. Croton megalobotrys - Setaria verticillata forest; G. Geigeria schinzii - Setaria sphacelata grassland; Jasminum stenolobur

FIGURE 3: Species richness (a), Simpson diversity index (b) and species evenness (c) for the eight plant communities in the Chobe Enclave. The black line is the median, boxes are limited by 1st and 3rd quartiles and the length of the whiskers corresponds to $1.5 \mathrm{SD}$. The number of sample plots included in the group is indicated above the whiskers in (a).

\section{Ipomoea chloroneura - Oxygonum alatum woodland}

This woodland community has a mean tree cover of $15.8 \% \pm$ $17.9 \%$ and a herb cover generally exceeding $80 \%$. It is found on river-washed sands, mainly in fossil alluvial channels or on stabilised sand dunes. Although soils are dominated by sand and classified as Arenosols (Romanens et al. 2019), they contain more silt $(2.5 \%-7.2 \%)$ and organic carbon than Aristida junciformis - Aristida meridionalis grasslands and have a slightly higher CEC (Table 2). Another major difference is the higher topographic position, resulting in the absence of a visible water table during the wet season. Diagnostic species are the woody species Grewia retinervis and Senegalia cinerea and the forbs Acanthosicyos naudinianus, Spermacoce senensis, Indigofera flavicans, Gisekia africana, Cleome hirta and Hermbstaedtia linearis. Many of these species are typical of porous, sandy soils (Heath \& Heath 2009; Sianga \& Fynn 2017). Panicum maximum, Urochloa trichopus and Dichrostachys cinerea are constant species. Terminalia sericea is largely dominant in some $75 \%$ of the plots, indicating deep sandy soils. This unit was previously described by Sianga and Fynn (2017) with a very similar species composition and ecological conditions. These plots were amongst the most species rich $(45.5 \pm 7.7$ species; Figure 3$)$.

\section{Baikiaea plurijuga - Baphia massaiensis forest}

These forests are fairly homogeneous in terms of structure and composition with dense woody strata: tree cover generally $>30 \%$ and a shrub cover $>8 \%$ (Table 1$)$. They are established on thick, reddish Kalahari sands, and soils are classified as Arenosols. These sands were deposited by wind (aeolian). Their red colour is because of an iron- and aluminum-rich oxyhydroxide coating, which contributes to acidifying the soil (Romanens et al. 2019), with the lowest soil $\mathrm{pH}$ in the CE (5.7-6.0; Table 2). Because of the elevation in the east of the geological fault, this plant community is completely disconnected from the hydrology that characterises the CE. As a result, plants have to rely on rainwater, which is quickly drained. The main diagnostic species are the woody species Combretum elaeagnoides, Baikiaea plurijuga, Baphia massaiensis, Combretum apiculatum, Croton gratissimus and Bauhinia petersiana, the grass Dactyloctenium giganteum and the forbs Jacquemontia tamnifolia, Ipomoea pes-tigridis, Syncolostemon 
bracteosus, Erlangea misera, Chamaecrista falcinella and Euphorbia crotonoides. Panicum maximum, Urochloa trichopus and Digitaria eriantha are constant and dominant grasses, and Phyllanthus pentandrus, Vigna unguiculata, Chamaecrista absus and Thunbergia aurea are constant forb species. According to Sianga and Fynn (2017), this plant community occupies large areas of the Chobe Forest Reserve. Its presence in northern Botswana is part of the western fringe of a very large distribution range in neighbouring Zimbabwe.

\section{Colophospermum mopane - Jasminum stenolobum woodland}

This woodland is dominated by Colophospermum mopane in both tree and shrub layers, but with a large variability in size. Some areas are characterised by tall specimens, whereas in other places $C$. mopane is limited to short specimens with a tree cover of $<1 \%$. Most of plots were located at slightly higher elevations, corresponding to fossil islands surrounded by sandy, alluvial deposits (McCarthy et al. 2012). The soil data indicate that C. mopane size corresponded to soil conditions. Shrubby individuals were found on soils with a silty and hard upper horizon characterised by a high CEC saturated by sodium (4.6-11.2 $\mathrm{cmol}^{+} \mathrm{kg}^{-1}$ ) and with high alkaline $\mathrm{pH}$ (9.4-10.2; Table 2). These soils were classified as Solonchak (Romanens et al. 2019). In contrast, tall trees were observed on soils with a sandy upper horizon, with moderate alkaline $\mathrm{pH}$ (7.0-8.2), but with the presence of a hard sodic horizon below $30 \mathrm{~cm}\left(8.2-11.8 \mathrm{cmol}^{+} \mathrm{kg}^{-1} \mathrm{de} \mathrm{Na}\right.$; $\left.\mathrm{pH} 9.8-11.3\right)$. These soils were classified as Solonetz or as other soil type with a salic horizon (Romanens et al. 2019). All plots were grouped in our clustering, but supplementary surveys may allow a subdivision in two groups corresponding to tree size. Besides C. mopane, the other diagnostic species are the Poaceae Schmidtia pappophoroides and Aristida adscensionis, both dominant, the Cyperaceae Kyllinga buchananii and the forbs Ipomoea coptica, Clerodendrum ternatum, Indigofera trita and Talinum caffrum. Moreover, Dichrostachys cinerea is constant. This community was previously described with a very similar species composition by Sianga and Fynn (2017), but some of their diagnostic species were rare in the CE. With a mean of $45.6 \pm 5.8$ species, these plots were amongst the most species rich (Figure 3).

\section{Eragrostis superba - Combretum hereroense woodland}

This woodland is established on a slightly higher elevation than the surrounding grasslands and therefore does not suffer from waterlogging. Tree cover is highly variable (range: $0 \%-80 \%$, mean: $16.9 \% \pm 21.6 \%$ ), and shrubs are always present. The soils are particularly fertile, because of the highest clay content of the study area $(14.2 \%-20.2 \%)$, which favours a high CEC dominated by calcium (4.7-17.2 $\mathrm{cmol}^{+} \mathrm{kg}^{-1}$ ), promoting an alkaline $\mathrm{pH}$ (Table 2). These soils were classified as Kastanozems (Romanens et al. 2019) and have a particularly low sand proportion $(<35 \%)$. The main diagnostic species are the dominant tree Combretum hereroense, along with the tree Sclerocarya birrea subsp. caffra, the Poaceae Eragrostis superba, Heteropogon contortus, which can be dominant and Urochloa oligotricha/brachyuria (two species difficult to distinguish in the field). The main diagnostic forbs are Rhynchosia minima, Asparagus africanus, Pechuel-loeschea leubnitziae, Hoslundia opposita and Hibiscus caesius (Online Appendix 2). Digitaria eriantha is a constant species, which can have very high cover (up to 70\%). Other constant species are Senegalia nigrescens and Solanum panduriforme. Cenchrus ciliaris is sometimes highly dominant. The composition of this plant community is variable, as many species can dominate locally but are absent in other plots. With a mean of $47.4 \pm 8.6$ species, it is particularly species rich, probably because of the heterogeneous tree cover and the regular presence of nitrogen fixing Leguminosae (e.g. Senegalia nigrescens, Philenoptera violacea), inducing a high diversity of conditions on small areas. Because a few species are often dominating the community, it has the lowest mean evenness $(0.37 \pm 0.08)$.

\section{Croton megalobotrys - Setaria verticillata forest}

This plant community is fragmented along the floodplains of the Linyanti River on substrates located higher than potentially waterlogged lowlands. It has the highest mean tree cover $(51.4 \% \pm 27.2 \%)$ and the tallest trees $(8.4 \pm 2.8 \mathrm{~m}$, Table 1). Compared with other plant communities, the alkaline soil, classified as Kastanozem (Romanens et al. 2019), showed intermediate values dominated by sand but with $14.9 \%-33.2 \%$ silt (Table 2). Species richness is high (47.9 \pm 9.8) with 24 diagnostic species (Online Appendix 2). The main species are the trees Berchemia discolor, Vachellia tortilis (locally dominant, with a cover up to 50\%) and Croton megalobotrys, the woody climbers Capparis tomentosa and Cocculus hirsutus, the shrub Grewia flavescens, the Poaceae Setaria verticillata and Setaria sagittifolia, and forbs such as Ipomoea dichroa, Acalypha fimbriata, Justicia heterocarpa, Achyranthes aspera, Dicliptera paniculata, Commelina petersii, Cyathula orthacantha, Pupalia lappacea, Tragia okanyua, Leonotis nepetifolia or Cocculus hirsutus (Online Appendix 2). The woody species Philenoptera violacea, Combretum mossambicense, Flueggea virosa and Dichrostachys cinerea and the grasses Panicum maximum and Urochloa trichopus are frequent and locally dominant. Finally, the woody species Kigelia africana, Terminalia prunioides and Ficus thonningii are quite rare, but were encountered in this plant community only, all with cover $\geq 10 \%$ (Online Appendix 1). This unit was previously described by Sianga and Fynn (2017).

\section{Geigeria schinzii - Setaria sphacelata grassland}

This grassland corresponds to the previously described dambos, defined as seasonally inundated grasslands, in shallow depressions, often characterised by the absence of a stream channel (Acres et al. 1985). Seasonal waterlogging hinders tree growth (Table 1). The low topographic position of these grasslands without a river draining the areas favours the accumulation of fine mineral material. In addition, waterlogging restrains organic matter mineralisation. Hence, these soils show the lowest sand content $(19.1 \%-28.7 \%)$, but highest silt $(58.8 \%-68.2 \%)$, 
organic carbon $(3.1 \%-5.1 \%)$ and CEC $\left(21.4-35.9 \mathrm{cmol}^{+} \mathrm{kg}^{-1}\right)$ compared with other plant communities (Table 2). The CEC is dominated by calcium (15.6-23.7 $\left.\mathrm{cmol}^{+} \mathrm{kg}^{-1}\right)$, resulting in a neutral to alkaline soil $\mathrm{pH}$. Soils were classified as Chernozems or Phaeozems (Romanens et al. 2019). Poaceae largely dominate the community, with Setaria sphacelata, Digitaria milanjiana, Hyparrhenia rufa, Bothriochloa bladhii, Ischaemum polystachyum and Leersia hexandra as diagnostic species, completed by the Asteraceae Geigeria schinzii and Linzia glabra (Table 2). Cynodon dactylon, Cymbopogon caesius, Panicum repens and Trachypogon spicatus are frequent and locally dominant Poaceae. Species richness is generally low $(27.0 \pm 3.6)$. The dominance of a few grass species results in a very low evenness $(0.38 \pm 0.08)$.

\section{Wet floodplain}

These plots were in areas with frequent or permanent soil waterlogging because of recurring flood events by the Linyanti River. These wetlands were insufficiently sampled because deep-flooded areas were difficult to access. Instead, plots were selected on the margins of the wetlands. Moreover, plots were highly variable, so that no common, good diagnostic species could be found. Cynodon dactylon and Enicostema axillare have their highest indicator values in wet floodplains, but are also frequent in Geigeria schinzii - Setaria sphacelata grasslands. Therefore, plots were grouped under the generic name of wet floodplains. However, this cannot be considered as a homogenous unit, and supplementary data are needed for a more precise description. The floodplain vegetation could certainly be divided in different plant communities, related to contrasted frequency and flood duration.

\section{Discussion}

Field sampling of 82 plots allowed a classification by clustering in eight plant communities. These plant communities were subsequently mapped with a supervised classification of remote sensing images. The CE can be divided into four landscape units (Figure 4): (1) the floodplains along the Linyanti River (north and northwest), fringed with Aristida junciformis - Aristida meridionalis grasslands, corresponding to the wetlands and dry floodplains on Sianga and Fynn's map (2017) and by C. megalobotrys - Setaria verticillata forests, mapped as riverine woodland on Sianga and Fynn's map (2017); (2) a mosaic of Eragrostis superba - Combretum hereroense woodlands and Geigeria schinzii - Setaria sphacelata grasslands in the central area, mapped as Acacia grasslands by Sianga and Fynn (2017); (3) a mosaic of Colophospermum mopane - Jasminum stenolobum woodlands and Ipomoea chloroneura - Oxygonum alatum woodlands in the western area, mapped as Mopane; and (4) the Baikiaea plurijuga - Baphia massaiensis forests in the eastern area, extending into the Chobe Forest Reserve.

\section{Floodplains}

The floodplains are under the influence of two major river systems: the Linyanti (called Kwando in its upstream part)

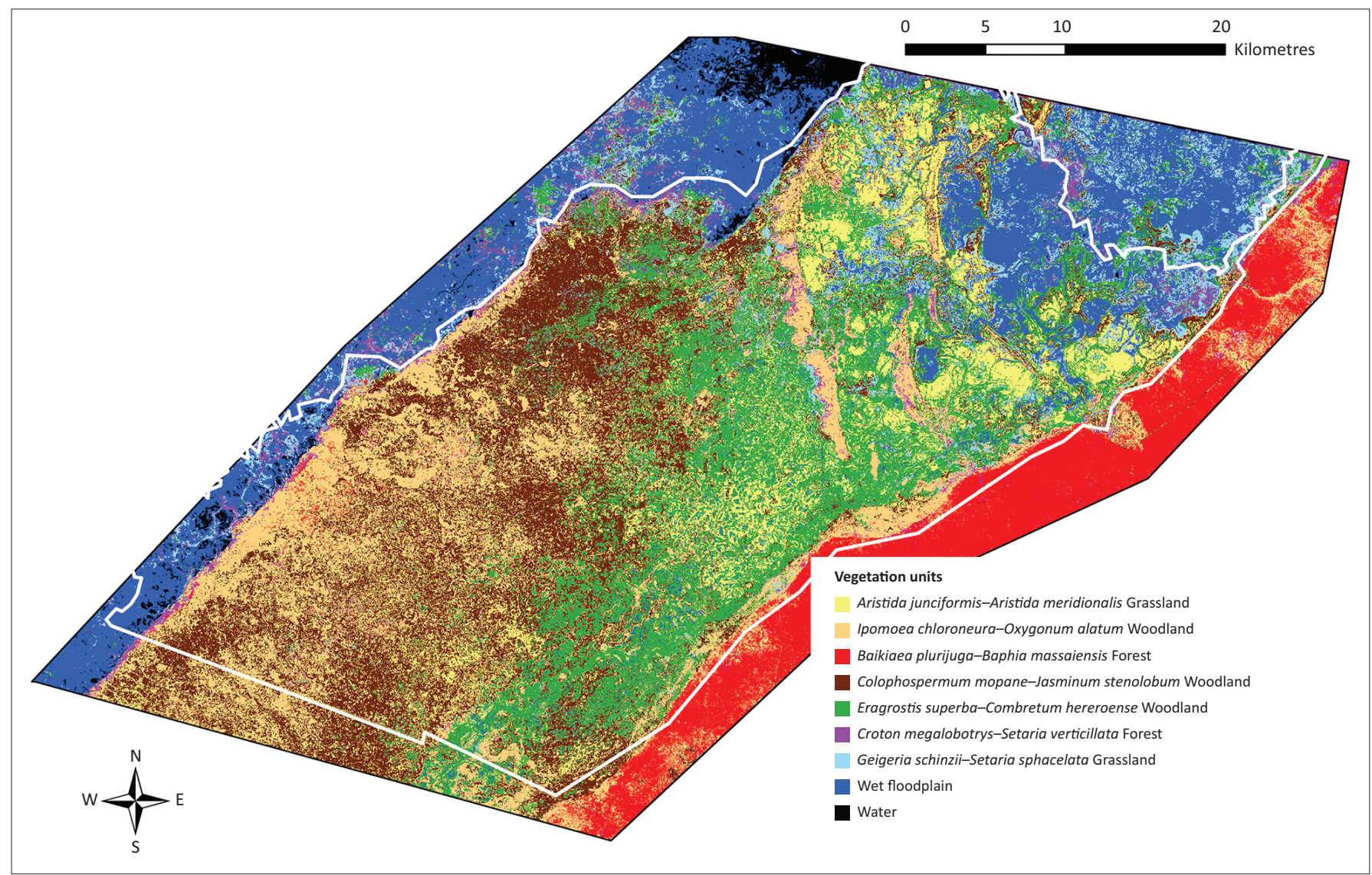

FIGURE 4: Vegetation map of the Chobe Enclave, delineated by the white line (a version in GIS file format is available upon request from the corresponding author). 
and the Zambezi. The Zambezi inflows push water back into the Chobe River, as far back as the CE (Pricope 2013). These rivers originate in Angolan highlands, $750 \mathrm{~km}$ further north. The amount of precipitations in both basins during the wet season controls the intensity of flooding and water table levels. Peak of flood pulses of both systems occur at different seasons: March-April for the Zambezi and June-July for the Linyanti (Pricope 2013). These flood peaks correspond to the end of the rainy season and dry season, respectively. Similar dynamics are observed in the Okavango Delta, where timing and duration of seasonal flooding are one of the important factors determining vegetation composition (Murray-Hudson et al. 2011). Seasonal flooding creates a zonation from permanent water (Lake Liambezi in the north) to areas with irregular flooding only. As stated above, our data set in the wetlands is insufficient to completely translate the diversity of plant communities. Supplementary data would allow the subdivision of the wet floodplains in various plant communities, as observed in the Okavango Delta (Murray-Hudson et al. 2011). A better description of these floodplains would be especially necessary as they are highly important for water and fodder availability to the wildlife during the dry season, with the gradient of flooding corresponding to variations in foraging time (Fynn et al. 2015).

Although floods are rare and shorter in the Aristida junciformis - Aristida meridionalis grasslands (higher topographical position), the water table is regularly high enough to reach plant roots. For plant growth, these dry floodplains present quite stressful conditions, which alternate between waterlogged soils at high water and very dry soils (well-draining sand) at the end of the dry season. Woody species of this plant community cannot cope with waterlogged periods, whereas with similar soils but clearly above the water table, trees and shrubs are an important component of the Ipomoea chloroneura - Oxygonum alatum woodlands. In dry ecosystems such as savannahs, trees are susceptible to facilitate grass growth by hydraulic lift (Priyadarshini et al. 2016), although the importance of this facilitation for the understorey is discussed (see Ludwig et al. 2004). However, facilitation does not occur in Aristida grasslands because of the absence of trees. This could explain the low species richness. An unmistakable characteristic of these dry floodplains is the numerous evenly distributed termite mounds (Mujinya et al. 2014), often occupied by trees (McCarthy et al. 1998). These mounds were excluded from our inventory because local ecological conditions were deemed too heterogeneous to fit into our sampling design. They rise above the floodplain, are rich in silt, clay, organic matter and nutrients and have a pH of 8-10 (Jouquet et al. 2011; Romanens et al. 2019). Some tree species occur almost exclusively on termite mounds (e.g. Phoenix reclinata, Imperata cylindrica; Roodt 1998). Supplementary smaller plots would be necessary to get a better knowledge of their species composition and variability.

At the margins of the floodplains are the riverine forests, classified as Croton megalobotrys - Setaria verticillata forest.
These forests are situated high enough to avoid flooding but low enough for riparian trees to reach the water table (Ellery \& Tacheba 2003). This ensures that trees have permanent access to water. These ideal conditions allow a high tree cover and the presence of many grasses and forbs. This results in a high species richness and $\alpha$-diversity (Figure 3). Many woody species are exclusively or mainly encountered in these forests. Termite mounds are also common, probably explaining the higher proportion of clay and silt in the soil, its higher CEC and alkaline pH (Romanens et al. 2019). Similar to wet floodplains, riverine vegetation provides an important dry season habitat for browsers and grazers owing to its ability to maintain green leaves over the dry season (Kleynhans et al. 2011).

\section{Central area}

In the central area, both distance to river and slope decreases flood frequency. The floodplains are replaced by a mosaic of depressions and slightly more elevated land. This microrelief creates contrasted ecological conditions, leading to the establishment of two distinct plant communities. The Geigeria schinzii - Setaria sphacelata grasslands (dambos) occupy the depressions, whereas the Eragrostis superba Combretum hereroense woodlands are located on higherlying grounds. The woodland substrate is dominated by a silty loam soil, rich in calcium carbonate (Romanens et al. 2019). This substrate, with high calcium and clay content in a sand-dominated landscape, probably originates from sedimentation in palaeolakes (Burrough \& Thomas 2008; Diaz et al. 2019).

The dambos do not have trees and are regarded as shallow, seasonally waterlogged, tropical and subtropical African wetlands. They are common in central and southern Africa, where an annual rainfall of $500 \mathrm{~mm}-1500 \mathrm{~mm}$ is concentrated over a wet season (Acres et al. 1985). Although they share the seasonal waterlogging with floodplains, the origin and timing of waterlogging differ. In dambos, the clay content of soils is responsible for retaining water and saturating the soil during the rainy season (Bullock 1992), whereas hydrological inflow of the floodplains originates from the Angolan highlands and arrives in the dry season. In dambos, waterlogging persists long enough to restrain organic matter mineralisation (Romanens et al. 2019). The high organic carbon and clay content explain the high CEC value, which induces a higher soil fertility than most of the other plant communities (Weil \& Brady 2017). These conditions allow tall grasses, mostly Setaria sphacelata, Cymbopogon caesius and Hyparrhenia rufa, to densely grow. This high density may explain the low species richness, as productive habitats have been shown to have the lowest species richness because of competitive exclusion of smaller species by the large dominants (Borer et al. 2014). These grasslands represent an important grazing resource by providing reliable green forage for zebra and other large herbivores during the dry season, especially after burning of old stubble (Fynn et al. 2014). Indeed, herbivores can graze the young, green grasses whilst the lack of trees 
provides high visibility around them as security against predators. The Eragrostis superba - Combretum hereroense woodlands have the same high clay and calcium content with a high CEC, and we can expect that these woodlands offer good quality forage also and shelter to the herbivores.

\section{Western area}

In the western part of the CE, a mosaic can be observed of Colophospermum mopane - Jasminum stenolobum and Ipomoea chloroneura - Oxygonum alatum woodlands. The latter corresponds to sandveld. From a bird's-eye view, this mosaic resembles a fossil delta with islands of Colophospermum woodlands separated by channels of sandveld. Old river meanders are locally clearly visible. This geomorphological pattern is inherited from ancient hydrological dynamics, with infilling of the channels by Kalahari sands (Fynn et al. 2014; Kinabo et al. 2008).

Colophospermum mopane is a deciduous tree on calcareous or sodic soils with a high clay content (Mapaure 1994; Roodt 1998). Its shallow root system enables growth on poorly drained substrates (Smit \& Rethman 1998). In the $\mathrm{CE}$, the soil conditions of these woodlands (high $\mathrm{pH}$ and CEC dominated by sodium) are similar to those of the islands of the Okavango Delta, where island centres are devoid of trees and shrubs because of a high sodium content (Ramberg \& Wolski 2008). This sodium constitutes a major osmotic stress for plants, reduces nutrient absorption and rainwater infiltration and tends to form a crust (Zhu 2001). Nevertheless, C. mopane tolerates these high alkaline conditions (Werger \& Coetzee 1978).

This woodland provides an ideal habitat for large herbivores such as buffalo, roan and sable antelopes or elephants. The leaves of $C$. mopane have a high nutritional value, with a high protein and phosphorus content, even when they have fallen on the ground (Roodt 1998). Moreover, the high clay content induces seasonal waterholes, and the salty soils under the patches of shrubby C. mopane provide saline grazing for wildlife (Sianga et al. 2017; Sianga \& Fynn 2017).

Dye and Walker (1980), Mapaure (1994) and Mlambo (2007) reported that $C$. mopane was characterised by a shrub structure on shallow, sodium-rich soils. In the CE, the soil under these stands had a hard upper horizon to dig, and crusts were observed. Conversely, tall mopanes grow on a $30 \mathrm{~cm}-75 \mathrm{~cm}$ deep layer of sand covering a hard sodiumrich horizon (Romanens et al. 2019; Roodt 1998), in line with Fraser, Van Rooyen and Verster's (1987) observations. Other studies assigned the short stature to elephant browsing (Smallie \& O'Connor 2000) or frequent fires (Mlambo \& Mapaure 2006), but the frequent presence of both forms close to each other, with distinct boundaries between them, indicates that soil chemistry is an important factor. However, our observations are based on a limited number of soil descriptions. Supplementary information would be necessary to confirm this separation.
In contrast to the Colophospermum mopane - Jasminum stenolobum woodlands, the Ipomoea chloroneura - Oxygonum alatum woodlands are characterised by very poor nutrient conditions. The scarcity of silt and clay induces dry and nutrient-poor conditions for plants. Indeed, the sandy structure has lower water retention and CEC than silty or clayey textures. In addition, nutrients are leached during the wet season. Consequently, soils are deficient in phosphorus and nitrogen (Roodt 1998; Sianga \& Fynn 2017). In the fossil palaeo-river channels, the proximity of very alkaline and fine material from Colophospermum woodland soils can explain the approximately neutral $\mathrm{pH}$. In contrast, the Baikiaea plurijuga-Baphia massaiensis forests are characterised by acidic soils because of aluminium (Romanens et al. 2019). These differences in $\mathrm{pH}$ induce different species compositions, but both units are attractive for grazers because they share a high cover of the palatable grasses Digitaria eriantha and Panicum maximum (Sianga et al. 2017; Sianga \& Fynn 2017).

\section{Functional habitat heterogeneity for herbivores}

Our detailed vegetation study, in combination with the parallel soil study, provides insight into the functional diversity of these habitats. Vegetation heterogeneity at a regional scale enables herbivores to adapt to changing conditions throughout the year (Sianga \& Fynn 2017). This study adds extra knowledge by (1) linking vegetation to soil characteristics and (2) showing the presence of previously undescribed plant communities for northern Botswana, such as dambos (Geigeria schinzii - Setaria sphacelata grassland) or Eragrostis superba - Combretum hereroense woodland on calcium- and clay-rich substrates and (3) by showing some interesting soil chemistryvegetation community relationships, such as Colophospermum mopane - Jasminum stenolobum woodland on saline soils. Herbivore population growth and reproduction critically depend on access to forage with high concentrations of energy, protein and key minerals such as calcium, sodium or phosphorus (Murray 1995; Parker, Barboza \& Gillingham 2009). Herbivores can access these resources by migrating to saline palaeolake systems (Nxai Pan, Makgadikgadi Pans and the Mababe Depression; Bartlam-Brooks, Bonyongo \& Harris 2011; Fynn et al. 2014; Naidoo et al. 2016). It is less clear, however, how non-migratory herbivores, such as buffalo, roan or sable antelopes (Bennitt et al. 2014; Haveman 2014; Hensman et al. 2013; Sianga et al. 2017), are able to access forage with sufficient concentrations of minerals for reproductive purposes. We can now hypothesise that the mosaic of C. mopane woodlands and sandveld provides a possible answer to this question. The high abundance of leafy grasses in sandveld, such as Digitaria eriantha and Panicum maximum, likely provide sufficient intake of digestible forage to meet energy and protein requirements, whilst plants and drinking water in pans in the C. mopane woodlands meet their mineral requirements. These two habitats occur in an extensive mosaic across the region so that herbivores can easily move between these functionally different habitats. 
During the dry season, when herbivores requires less resources (no lactation or rapid growth requirements), the availability of forage and its quality declines greatly (OwenSmith 2008). Without access to functional key resource habitats to provide reserves of adequate-quality forage for survival, herbivore populations would collapse during drought years (Illius \& O'Connor 2000; Walker et al. 1987). In the $\mathrm{CE}$, the floodplains, dambos and riverine forests provide access to grasses and a shallow water table that enables the maintenance of green forage during the dry season. The simultaneous flood of the Linyanti River ensures a reliable source of drinking water (Fynn et al. 2014).

\section{The vegetation map limitations}

Based on field experience and a lower resolution map (Sianga \& Fynn 2017), we are confident that our vegetation map (Figure 4) corresponds to the distribution of forests, woodlands and grasslands. Moreover, it reflects the general distribution of the various plant communities. Compared with Sianga and Fynn (2017), its higher resolution enabled the elucidation of small-sized plant communities that are locally restricted to the CE, such as Geigeria schinzii - Setaria sphacelata grasslands. However, some pixels of the grasslands can be misinterpreted. For example, the presence of Geigeria schinzii - Setaria sphacelata grassland on the edges of the floodplains does not correspond to their distribution and ecological conditions. The light blue areas shown in northern part of Figure 4 are more probably variations amongst wet floodplains. Conversely, the dark blue patches (wet floodplains) around the centre and south of the map ought probably to be light blue (Figure 4), as these sites are too far away and too isolated from the river to be flooded, but only stay wet during the rainy season. A possible explanation is that the similar vegetation structure of these grasslands, with common species, and their wet soils resulted in too close a reflectance in remote sensing data for accurate discrimination.

Transition zones can be expected amongst woodlands with intermediate conditions from Eragrostis superba-Combretum hereroense woodland to Colophospermum mopane - Jasminum stenolobum woodland (Romanens et al. 2019). Finally, isolated pixels attributed to Croton megalobotrys - Setaria verticillata forest or to Baikiaea plurijuga - Baphia massaiensis forest in the central part of the map are artefacts because of an insufficient number of pixels covering small patches of trees (Figure 4).

\section{Conclusion}

At the landscape scale, the CE is flat and dominated by sand. However, over time, water and tectonic activity diversified the microtopography and chemistry of the substrates. This microtopography also induced a gradient of soil texture, parallel to the flooding potential. All these variations create a mosaic of soil units, with their respective nutrient availability (Romanens et al. 2019). The same parameters and their corresponding soils are the environmental drivers for a diversity of plant communities. These plant communities offer a diversity of resources, allowing some herbivores to live in the area all the year round. Supplementary data of the wet floodplain and in areas of permanent water are needed to classify these plant communities at a similar level of detail. The vegetation classification and mapping of this spatially heterogenous landscape will provide an excellent baseline for future studies on seasonal habitat use by herbivores in the CE.

\section{Acknowledgements}

We express our sincere thanks to the Ministry of Environment, Natural Resources Conservation and Tourism of the Republic of Botswana as well as the Chobe Enclave Conservation Trust for the research permits, without which this study would not have been possible. We are grateful to the three anonymous reviewers and to Jesse M. Kalwij, whose comments helped us to improve our manuscript, and to Karin Verrecchia, who kindly edited the revised version of the manuscript.

\section{Competing interests}

The authors declare that they have no financial or personal relationships that may have inappropriately influenced this article.

\section{Authors' contributions}

P.V., F.P., E.P.V. and R.F. designed the study; F.P., R.R., A.M., P.V. and R.F. realised the field work; F.P. and P.V. analysed the data; and all authors contributed to the writing of the manuscript.

\section{Ethical consideration}

No ethical clearance was required for this study.

\section{Funding information}

This work has been partly supported by a Swiss National Foundation grant no. 200021_172944 to Eric P. Verrecchia.

\section{Data availability statement}

All data are available in the online version of this article as Online Appendix 1 (table of the 82 plant inventory plots) and Online Appendix 2 (synoptic tables for the 8 plant communities).

\section{Disclaimer}

The views and opinions expressed in this article are those of the authors and do not necessarily reflect the official policy or position of any affiliated agency of the authors.

\section{References}

Acres, B.D., Blair Rains, A., King, R.B., Lawton, R.M., Mitchell, A.J.B. \& Rackham, L.J., 1985, 'African dambos: Their distribution, characteristics and use', Zeitschrift fur Geomorphologie 52(1), 62-83. 
Bartlam-Brooks, H.L.A., Bonyongo, M.C. \& Harris, S., 2011, 'Will reconnecting ecosystems allow long-distance mammal migrations to resume? A case study of a zebra Equus burchelli migration in Botswana', Oryx 45(2), 210-216. https://doi. zebra Equus burchelli migration in
org/10.1017/S0030605310000414

Bennitt, E., Bonyongo, M.C. \& Harris, S., 2014, 'Habitat selection by African buffalo (Syncerus caffer) in response to landscape-level fluctuations in water availability on two temporal scales', PLoS One 9(7), e101346. https://doi.org/10.1371/journal. pone.0101346

Borer, E.T., Seabloom, E.W., Gruner, D.S., Harpole, W.S., Hillebrand, H., Lind, E.M., et al., 2014, 'Herbivores and nutrients control grassland plant diversity via light limitation', Nature 508(7497), 517-520. https://doi.org/10.1038/nature13144

Bullock, A., 1992, 'Dambo hydrology in southern Africa - Review and reassessment', Journal of Hydrology 134(1-4), 373-396. https://doi.org/10.1016/0022 1694(92)90043-U

Burrough, S.L. \& Thomas, D.S.G., 2008, 'Late quaternary lake-level fluctuations in the Mababe Depression: Middle Kalahari Palaeolakes and the role of Zambezi inflows', Quaternary Research 69(3), 388-403. https://doi.org/10.1016/j.yqres.2008.02.003

Chase, M., 2013, Status of wildlife populations and land degradation in Botswana's Forest Reserves and Chobe District, Unpublished report, Forest Conservation Botswana, Elephants Without Borders, Zoological Society of San Diego.

De Cáceres, M., Chytrý, M., Agrillo, E., Attorre, F., Botta-Dukát, Z., Capelo, J. et al., 2015 'A comparative framework for broad-scale plot-based vegetation classification', Applied Vegetation Science 18(4), 543-560. https://doi.org/10.1111/avsc.12179

Diaz, N., Armitage, S.J., Verrecchia, E.P. \& Herman, F., 2019, 'OSL dating of a carbonate island in the Chobe Enclave, NW Botswana', Quaternary Geochronology 49(1) 172-176. https://doi.org/10.1016/j.quageo.2018.03.001

Dufrêne, M. \& Legendre, P., 1997, 'Species assemblages and indicator species: The need for a flexible asymmetrical approach', Ecological Monographs 67(3), 345366. https://doi.org/10.1890/0012-9615(1997)067[0345:SAAIST]2.0.CO;2

Dye, P. \& Walker, B., 1980, 'Vegetation-environment relations on sodic soils of Zimbabwe-Rhodesia', Journal of Ecology 68(2), 589-606. https://doi. org/10.2307/2259424

Ellery, W.N. \& Tacheba, B., 2003, 'Floristic diversity of the Okavango Delta, Botswana. A rapid biological assessment of the aquatic ecosystems of the Okavango Delta, Botswana: High water survey', RAP-Bulletin of Biological Assessment 25(1), 69-96.

ESRI, 2019, World imagery and national geographic base maps, Sources: ESRI, DigitalGlobe, GeoEye, Earthstar Geographics, CNES/Airbus DS, USDA, USGS, AeroGRID, IGN, and the GIS User Community.

Ewald, J., 2003, 'A critique for phytosociology', Journal of Vegetation Science 14(2), 291-296. https://doi.org/10.1111/j.1654-1103.2003.tb02154.x

Fraser, S.W., Van Rooyen, T.H. \& Verster, E., 1987, 'Soil-plant relationships in the central Kruger National Park', Koedoe 30(1), 19-34. https://doi.org/10.4102/ koedoe.v30i1.499

Fynn, R.W.S., Chase, M. \& Röder, A., 2014, 'Functional habitat heterogeneity and large herbivore seasonal habitat selection in northern Botswana', South African Journal of Wildlife Research 44(1), 1-15. https://doi.org/10.3957/056.044.0103

Fynn, R.W.S., Murray-Hudson, M., Dhliwayo, M. \& Scholte, P., 2015, 'African wetlands and their seasonal use by wild and domestic herbivores', Wetlands Ecology and Management 23(1), 559-581. https://doi.org/10.1007/s11273-015-9430-6

Gongedo, L., 2017, Semi-automatic classification plugin documentation, Release 5.3.6.1 viewed 28 September 2020, from https://semiautomaticclassificationmanual-v5. readthedocs.io/en/latest/

Hartigan, J.A., 1975, Clustering algorithms, Wiley, New York, NY.

Haveman, C.P., 2014, 'Population dynamics and foraging ecology of roan antelope in northern Botswana', MSc thesis, University of Pretoria.

Heath, R. \& Heath, A., 2009, Field guide to the plants of Northern Botswana including the Okavango Delta, Royal Botanic Gardens, Richmond.

Hensman, M.C., Owen-Smith, N., Parrini, F. \& Bonyongo, M.C., 2013, 'Resource use and the nutritional status of sable antelope in the Okavango Delta region of northern Botswana', African Journal of Ecology 52(3), 237-245. https://doi. org/10.1111/aje.12113

Illius, A.W. \& O'Connor, T.G., 2000, 'Resource heterogeneity and ungulate population dynamics', Oikos 89(2), 283-294. https://doi.org/10.1034/j.1600-0706.2000. 890209.x

Ischer, M., Dubuis, A., Keller, R. \& Vittoz, P., 2014, 'A better understanding of ecological conditions for Leontopodium alpinum Cassini in the Swiss Alps', Folia Geobotanica 49(4), 541-558.

IUSS Working Group WRB, 2014, World reference base for soil resources 2014 International soil classification system for naming soils and creating legends for soil maps, FAO, Rome.

Jones, B., 2002, Chobe Enclave, Botswana - Lessons learnt from a CBNRM project 1993-2002, CBNRM Support Project, Gaborone.

Jouquet, P., Traoré, S., Choosai, C., Hartmann, C. \& Bignell, D., 2011, 'Influence of termites on ecosystem functioning. Ecosystem services provided by termites' European Journal of Soil Biology 47(4), 215-222. https://doi.org/10.1016/j. ejsobi.2011.05.005

Kinabo, B.D., Hogan, J.P., Atekwana, E.A., Abdelsalam, M.G. \& Modisi, M.P., 2008 'Fault growth and propagation during incipient continental rifting: Insights from a combined aeromagnetic and Shuttle Radar Topography Mission digital elevation model investigation of the Okavango Rift Zone, northwest Botswana', Tectonic 27(3), TC3013. https://doi.org/10.1029/2007TC002154

Kleynhans, E.J., Jolles, A.E., Bos, M.R.E. \& Olff, H., 2011, 'Resource partitioning along multiple niche dimensions in differently sized African savanna grazers', Oikos 120(4), 591-600. https://doi.org/10.1111/j.1600-0706.2010.18712.x
Kyalangalilwa, B., Boatwright, J.S., Daru, B.H., Maurin, O. \& van der Bank, M., 2013, 'Phylogenetic position and revised classification of Acacia s.l. (Fabaceae: Mimosoideae) in Africa, including new combinations in Vachellia and Senegalia' Botanical Journal of the Linnean Society 172(4), 500-523. https://doi.org/10.1111/ boj.12047

udwig, F., Dawson, T.E., Prins, H.H.T., Berendse, F. \& de Kroon, H., 2004, 'Belowground competition between trees and grasses may overwhelm the facilitative effects of hydraulic lift', Ecology Letters 7(8), 623-631. https://doi.org/10.1111/ j.1461-0248.2004.00615.x

Mapaure, I., 1994, 'The distribution of Colophospermum mopane (LeguminosaeCaesalpinioideae) in Africa', Kirkia 15(1), 1-5.

McCarthy, T.S., 2013, 'The Okavango Delta and its place in the geomorphological evolution of southern Africa', South African Journal of Geology 116(1), 1-54. https://doi.org/10.2113/gssajg.116.1.1

McCarthy, T.S., Ellery, W.N. \& Dangerfield, J.M., 1998, 'The role of biota in the initiation and growth of islands on the floodplain of the Okavango alluvial fan, Botswana', Earth Surface Processes and Landforms 23(4), 291-316.

McCarthy, T.S., Humphries, M.S., Mahomed, I., Le Roux, P. \& Verhagen, B.Th., 2012 'Island forming processes in the Okavango Delta, Botswana', Geomorphology 179(1), 249-257. https://doi.org/10.1016/j.geomorph.2012.08.016

McClean, C.J., Doswald, N., Kuper, W., Sommer, J.H., Barnard, P. \& Lovett, J.C., 2006, 'Potential impacts of climate change on Sub-Saharan African plant priority area selection', Diversity and Distributions 12(6), 645-655. https://doi.org/10.1111/ j.1472-4642.2006.00290.x

Mlambo, D., 2007, 'Influence of soil fertility on the physiognomy of the African savanna tree Colophospermum mopane', African Journal of Ecology 45(1), 109-111. https:// doi.org/10.1111/j.1365-2028.2006.00676.x

Mlambo, D. \& Mapaure, I., 2006, 'Post-fire resprouting of Colophospermum mopane saplings in a southern African savanna', Journal of Tropical Ecology 22(2), 231-234. https://doi.org/10.1017/S026646740500297X

Mujinya, B.B., Adam, M., Mees, F., Bogaert, J., Vranken, I., Erens, H. et al., 2014 'Spatial patterns and morphology of termite (Macrotermes falciger) mounds in the Upper Katanga, DR Congo', CATENA 114(1), 97-106. https://doi.org/10.1016/j. catena.2013.10.015

Murray, M.G., 1995, 'Specific nutrient requirements and migration of wildebeest', in A.R.E. Sinclair \& P. Arcese (eds.) Serengeti II: Dynamics, management, and A.R.E. Sinclair \& P. Arcese (eds.) Serengeti II: Dynamics, management, and
conservation of an ecosystem, pp. 231-256, The University of Chicago Press, Conservation

Murray-Hudson, M., Combs, F., Wolski, P. \& Brown, M.T., 2011, 'A vegetation-based hierarchical classification for seasonally pulsed floodplains in the Okavango Delta, Botswana', African Journal of Aquatic Science 36(3), 223-234. https://doi.org/10. 2989/16085914.2011.636904

Naidoo, R., Chase, M.J., Beytell, P., Du Preez, P., Landen, K., Stuart-Hill, G. et al., 2016 , 'A newly discovered wildlife migration in Namibia and Botswana is the longest in Africa', Oryx 50(1), 138-146. https://doi.org/10.1017/\$0030605314000222

Owen-Smith, N., 2008, 'Effects of temporal variability in resources on foraging behaviour', in H.H.T. Prins \& F. Van Langevelde (eds.), Resource ecology: Spatial and temporal dynamics of foraging, pp. 159-181, Springer, Dordrecht.

Parker, K.L., Barboza, P.S. \& Gillingham, M.P., 2009, 'Nutrition integrates environmental responses of ungulates', Functional Ecology 23(1), 57-69. https://doi. org/10.1111/j.1365-2435.2009.01528.x

Perumal, K. \& Bhaskaran, R., 2010, 'Supervised classification performance of multispectral images', Journal of Computing 2(2), 124-129.

Pricope, N.G., 2013, 'Variable-source flood pulsing in a semi-arid transboundary watershed: The Chobe River, Botswana and Namibia', Environmental Monitoring and Assessment 185(2), 1883-1906. https://doi.org/10.1007/s10661-012-2675-0

Pricope, N.G., Gaughan, A.E., All, J.D., Binford, M.W. \& Rutina, L.P., 2015 'Spatio-temporal analysis of vegetation dynamics in relation to shifting inundation and fire Regimes: Disentangling environmental variability from land management decisions in a southern African transboundary watershed', Land 4(3), 627-655. https://doi.org/10.3390/land4030627

Priyadarshini, K.V.R., Prins, H.H.T., de Bie, S., Heitkonig, I.M.A., Woodborne, S., Gort, G et al., 2016, 'Seasonality of hydraulic redistribution by trees to grasses and
changes in their water-source use that change tree-grass interactions', changes in their water-source use that change tree-grass
Ecohydrology $9(2), 218-228$. https://doi.org/10.1002/eco.1624

Ramberg, L. \& Wolski, P., 2008, 'Growing islands and sinking solutes: Processes maintaining the endorheic Okavango Delta as a freshwater system', Plant Ecology 196(2), 215-231. https://doi.org/10.1007/s11258-007-9346-1

Romanens, R., Pellacani, F., Mahinga, A., Fynn, R., Vittoz, P. \& Verrecchia, E.P., 2019 'Soil diversity and major soil processes in the Kalahari basin, Botswana', Geoderma Regional 19(1), e00236. https://doi.org/10.1016/j.geodrs.2019.e00236

Roodt, V., 1998, Trees \& shrubs of the Okavango delta: Medicinal uses and nutritional value, Shell Oil Botswana (Pty) Ltd, Maun.

Roodt, V., 2015, Grasses \& grazers of Botswana and the surrounding savanna, Struik Nature, Cape Town.

Sala, O.E., Chapin, F.S., Armesto, J.J., Berlow, E., Bloomfield, J., Dirzo, R. et al., 2000 'Biodiversity - Global biodiversity scenarios for the year 2100', Science 287(5459), 1770-1774. https://doi.org/10.1126/science.287.5459.1770

Schmidt, C., 2017, Advanced land cover classification Webinar Series, Applied Remote Sensing Training (ARSET), NASA, viewed 28 September 2020, from https://arset. gsfc.nasa.gov/land/webinars/advanced-land-classification.

Sianga, K. \& Fynn, R., 2017, 'The vegetation and wildlife habitats of the SavutiMababe-Linyanti ecosystem, northern Botswana', Koedoe 59(2), 1-16. https:// doi.org/10.4102/koedoe.v59i2.1406 
Sianga, K., Van Telgen, M., Vrooman, J., Fynn, R.W.S. \& Van Langevelde, F., 2017 'Spatial refuges buffer landscapes against homogenisation and degradation by 'Spatial refuges buffer landscapes against homogenisation and degradation by 59(2), a1434. https://doi.org/10.4102/koedoe.v59i2.1434

Smallie, J.J. \& O'Connor, T.G., 2000, 'Elephant utilization of Colophospermum mopane: Possible benefits of hedging', African Journal of Ecology 38(4), 352-359. https:// doi.org/10.1046/j.1365-2028.2000.00258.x

Smit, G.N. \& Rethman, N.F.G., 1998, 'Root biomass, depth distribution and relations with leaf biomass of Colophospermum mopane, South African Journal of Botany 64(1), 38-43. https://doi.org/10.1016/S0254-6299(15)30825-5

Walker, B.H., Emslie, R.H., Owen-Smith, R.N. \& Scholes, R.J., 1987, 'To cull or not to cull: Lessons from a Southern African drought', Journal of Applied Ecology 24(2), 381-401. https://doi.org/10.2307/2403882
Walker, D.A., Daniels, F.J.A., Alsos, I., Bhatt, U.S., Breen, A.L., Buchhorn, M. et al., 2016 'Circumpolar Arctic vegetation: A hierarchic review and roadmap toward an internationally consistent approach to survey, archive and classify tundra plot data', Environmental Research Letters 11(5), 055005. https://doi.org/10.1088/17489326/11/5/055005

Weil, R.R. \& Brady, N.C., 2017, The nature and properties of soils, 15th edn., Pearson, Harlow.

Werger M.J.A. \& Coetzee, B.J. 1978, 'The Sudano-Zambezian Region', in M.J.A. Werger (ed.), Biogeography and ecology of southern Africa, pp. 301-462, Springer, Dordrecht. Wildi, O., 2010, Data analysis in vegetation ecology, Wiley-Blackwell, Chichester.

Zhu, J.K., 2001, 'Plant salt tolerance', Trends in Plant Science 6(2), 66-71. https://doi. org.10.1016/s1360-1385(00)01838-0 


\section{Appendices}

\section{Appendix 1}
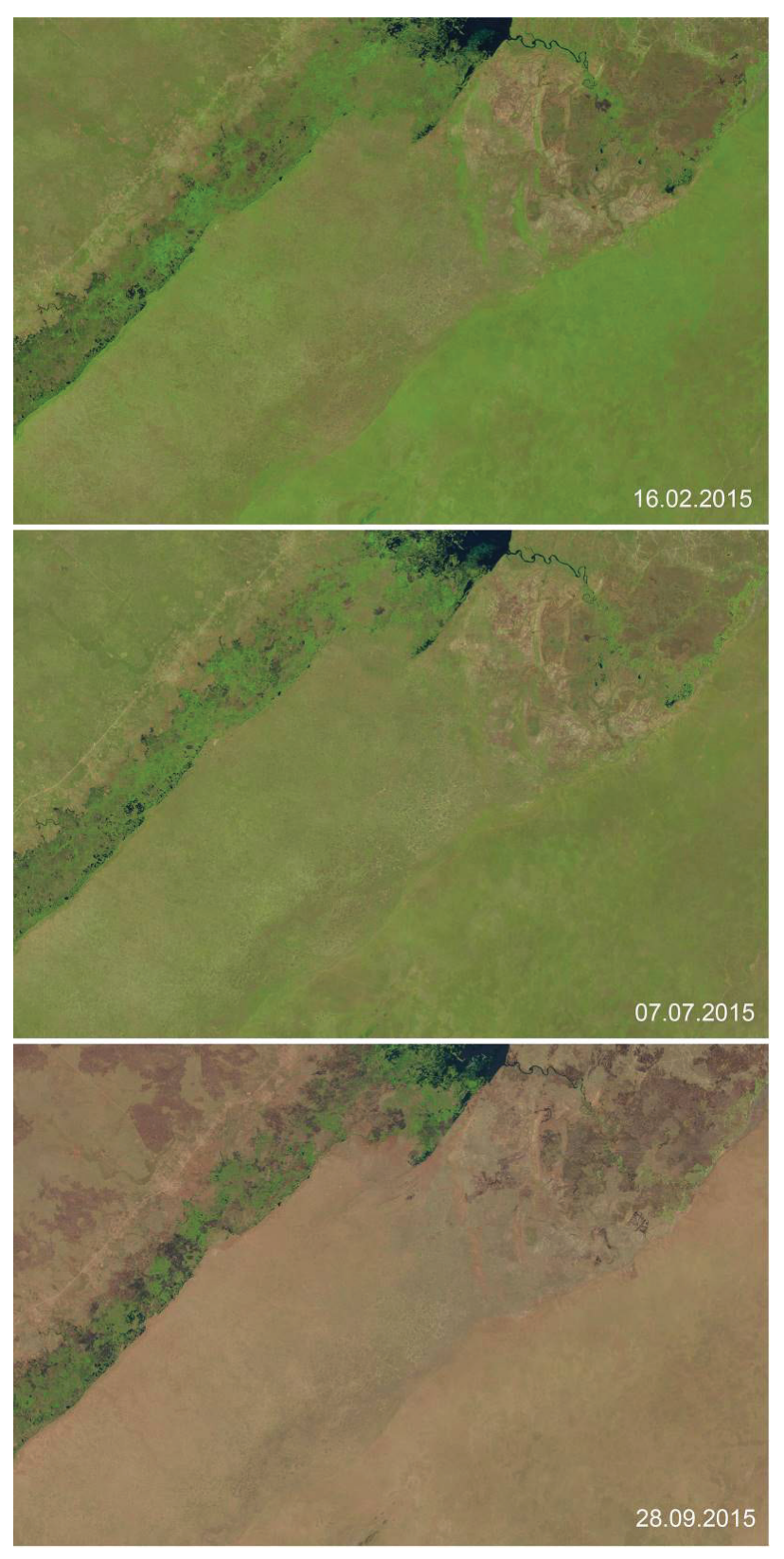

Source: USGS/NASA Landsat

FIGURE 1-A1: True colour Landsat 8 images of the Chobe Enclave for the different seasons: February is in the middle of the rainy season, May at the end of the rainy season and September in the dry season. 


\section{Appendix 2}

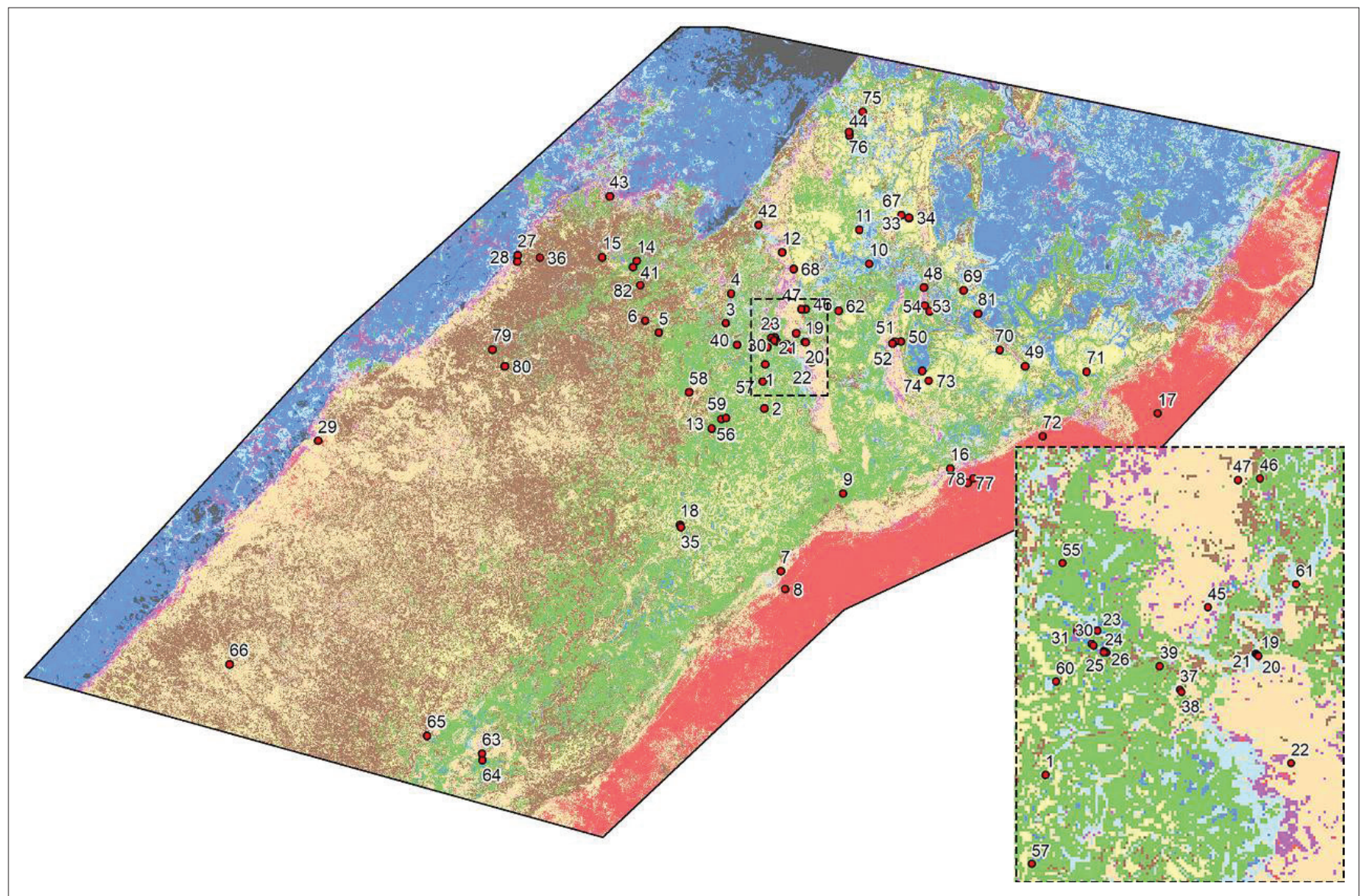

FIGURE 1-A2: Distribution of the 82 sampling plots in the Chobe Enclave. The inset on the right is an enlargement of the central rectangle. 


\section{Appendix 3}

Table 1-A3: Coordinates of the 82 sampling plots in the Chobe Enclave. Measurements refer to the centre of the plot and were taken with a Garmin GPS (precision 3-5 $\mathrm{m}$ ). Coordinates are indicated according to the UTM zone 35South (WGS 84).

\begin{tabular}{|c|c|c|c|c|c|c|c|c|}
\hline \multirow{2}{*}{$\frac{\text { Code }}{1}$} & \multicolumn{2}{|c|}{ Coordinates } & \multirow{2}{*}{$\begin{array}{r}\text { Code } \\
29\end{array}$} & \multicolumn{2}{|c|}{ Coordinates } & \multirow{2}{*}{$\begin{array}{r}\text { Code } \\
57\end{array}$} & \multicolumn{2}{|c|}{ Coordinates } \\
\hline & $215424 \mathrm{E}$ & $7993857 N$ & & $187370 E$ & $7989132 N$ & & $215256 \mathrm{E}$ & $7992812 \mathrm{~N}$ \\
\hline 2 & $215363 E$ & $7991135 N$ & 30 & $215970 \mathrm{E}$ & $7995390 N$ & 58 & $210642 \mathrm{E}$ & $7992151 N$ \\
\hline 3 & $212952 E$ & $7996426 \mathrm{~N}$ & 31 & $215795 E$ & $7995538 \mathrm{~N}$ & 59 & $212971 \mathrm{E}$ & $7990560 \mathrm{~N}$ \\
\hline 4 & $213301 \mathrm{E}$ & $7998269 N$ & 32 & $215990 \mathrm{E}$ & $7995370 \mathrm{~N}$ & 60 & $215549 \mathrm{E}$ & $7994949 N$ \\
\hline 5 & $208748 E$ & $7995853 N$ & 33 & $224427 E$ & $8002968 N$ & 61 & $218388 \mathrm{E}$ & $7996087 \mathrm{~N}$ \\
\hline 6 & 207891E & $7996587 N$ & 34 & $224432 E$ & $8002990 \mathrm{~N}$ & 62 & $220024 \mathrm{E}$ & $7997201 N$ \\
\hline 7 & $216408 \mathrm{E}$ & $7981036 \mathrm{~N}$ & 35 & $210140 \mathrm{E}$ & $7983775 N$ & 63 & $197672 \mathrm{E}$ & $7969712 \mathrm{~N}$ \\
\hline 8 & $216698 \mathrm{E}$ & $7979927 N$ & 36 & $201283 E$ & $8000508 \mathrm{~N}$ & 64 & 197694E & $7969322 \mathrm{~N}$ \\
\hline 9 & $220327 E$ & $7985872 \mathrm{~N}$ & 37 & $217016 \mathrm{E}$ & $7994851 \mathrm{~N}$ & 65 & 194209E & $7970824 \mathrm{~N}$ \\
\hline 10 & $221959 E$ & $8000123 N$ & 38 & $217033 \mathrm{E}$ & $7994822 \mathrm{~N}$ & 66 & $181830 \mathrm{E}$ & $7975252 \mathrm{~N}$ \\
\hline 11 & $221333 E$ & $8002247 N$ & 39 & $216775 E$ & $7995128 \mathrm{~N}$ & 67 & $223961 \mathrm{E}$ & $8003150 \mathrm{~N}$ \\
\hline 12 & $216486 \mathrm{E}$ & $8000834 N$ & 40 & $213646 E$ & $7995093 N$ & 68 & 217194E & $7999804 N$ \\
\hline 13 & $212062 E$ & $7989891 \mathrm{~N}$ & 41 & 207124E & $7999898 N$ & 69 & $227857 \mathrm{E}$ & $7998485 \mathrm{~N}$ \\
\hline 14 & $207358 E$ & $8000295 N$ & 42 & 214996E & $8002537 \mathrm{~N}$ & 70 & $230131 E$ & $7994773 N$ \\
\hline 15 & $205216 E$ & $8000541 \mathrm{~N}$ & 43 & 205683E & $8004326 \mathrm{~N}$ & 71 & $235587 E$ & $7993426 \mathrm{~N}$ \\
\hline 16 & $227037 \mathrm{E}$ & $7987415 N$ & 44 & $220703 E$ & $8008110 \mathrm{~N}$ & 72 & $232829 E$ & $7989414 N$ \\
\hline 17 & $240048 E$ & $7990827 \mathrm{~N}$ & 45 & 217349E & $7995818 \mathrm{~N}$ & 73 & $225681 E$ & $7992855 N$ \\
\hline 18 & $210087 E$ & $7983925 \mathrm{~N}$ & 46 & 217964E & $7997324 N$ & 74 & $225260 \mathrm{E}$ & $7993480 \mathrm{~N}$ \\
\hline 19 & 217914E & $7995275 N$ & 47 & $217703 E$ & $7997306 \mathrm{~N}$ & 75 & $221530 \mathrm{E}$ & $8009559 N$ \\
\hline 20 & $217930 \mathrm{E}$ & $7995260 \mathrm{~N}$ & 48 & $225371 \mathrm{E}$ & $7998652 \mathrm{~N}$ & 76 & $220673 E$ & $8008295 \mathrm{~N}$ \\
\hline 21 & $217945 E$ & $7995245 N$ & 49 & $231717 \mathrm{E}$ & $7993777 N$ & 77 & $228130 \mathrm{E}$ & $7986542 \mathrm{~N}$ \\
\hline 22 & $218335 E$ & $7993992 \mathrm{~N}$ & 50 & 223935E & $7995286 \mathrm{~N}$ & 78 & $228482 E$ & $7986800 \mathrm{~N}$ \\
\hline 23 & $216040 \mathrm{E}$ & $7995545 \mathrm{~N}$ & 51 & $223568 \mathrm{E}$ & $7995289 N$ & 79 & $198311 \mathrm{E}$ & $7994799 N$ \\
\hline 24 & $216145 E$ & $7995285 N$ & 52 & $223409 E$ & $7995170 \mathrm{~N}$ & 80 & $199078 \mathrm{E}$ & $7993777 N$ \\
\hline 25 & $216113 E$ & $7995305 \mathrm{~N}$ & 53 & $225412 E$ & $7997516 \mathrm{~N}$ & 81 & $228773 E$ & $7997030 \mathrm{~N}$ \\
\hline 27 & 199893E & $8000657 \mathrm{~N}$ & 55 & $215625 E$ & $7996332 \mathrm{~N}$ & & & \\
\hline 28 & $199858 E$ & $8000248 \mathrm{~N}$ & 56 & $212670 \mathrm{E}$ & $7990470 \mathrm{~N}$ & & & \\
\hline
\end{tabular}




\section{Appendix 4}

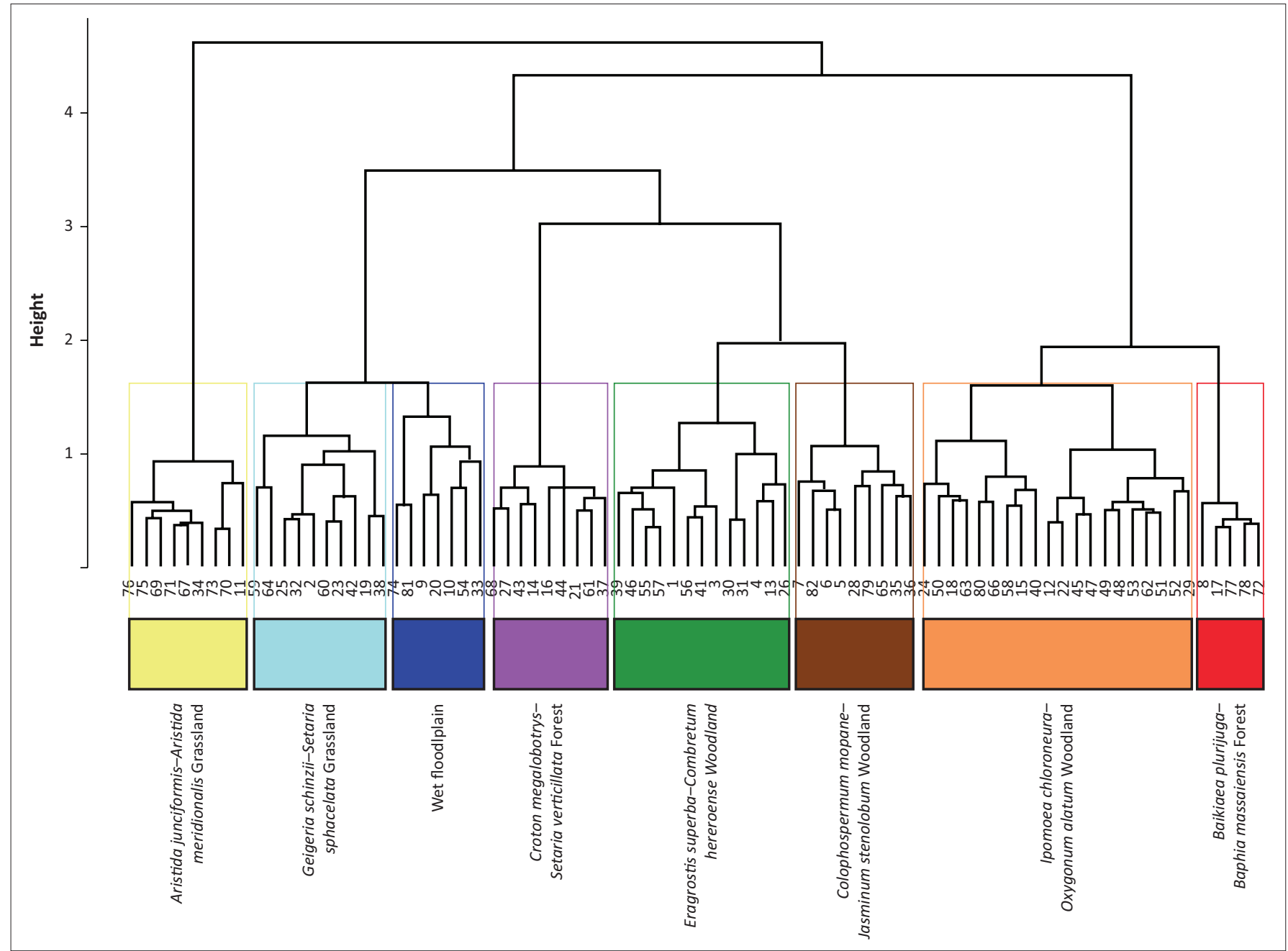

FIGURE 1-A4: Hierarchical clustering of the plant inventory plots $(N=82)$ in the Chobe Enclave based on the Bray-Curtis distance and the Ward's minimum variance method. 